\title{
Pain in Oral and Maxillofacial Surgery and Implant Dentistry: Types and Management
}

\author{
Diane Isabel Selvido ${ }^{1, \odot}$ Bishwa Prakash Bhattarai ${ }^{1, \odot} \quad$ Dinesh Rokaya ${ }^{1, \odot} \quad$ Nattisa Niyomtham²,๑ \\ Natthamet Wongsirichat ${ }^{1, \odot}$
}

${ }^{1}$ Department of Clinical Dentistry, Walailak University International College of Dentistry, Walailak University, Bangkok, Thailand

${ }^{2}$ Department of Oral Bioscience and Dental Public Health, Walailak University International College of Dentistry, Walailak University, Bangkok, Thailand

\begin{abstract}
Address for correspondence Bishwa Prakash Bhattarai, BDS, MScD (OMFS), Department of Clinical Dentistry, Walailak University International College of Dentistry, Walailak University, 979/42-46 Phahonyothin Road, 19th floor SM Tower, Phaya Thai District, Bangkok 10400, Thailand (e-mail: bishwa052@gmail.com).
\end{abstract}

Eur J Dent 2021;15:588-598
Abstract
Keywords
- pain
- oral and maxillofacial surgery
- surgical intervention
- clinical studies
- tissue damage

Over the years, the pain has been defined numerous times in several ways. In oral and maxillofacial surgery, the occurrence of pain, especially postoperatively, is anticipated. Pain arises as a combination of various processes after tissue damage. Distinct pain experiences in oral surgery were depicted in several previous studies, adding knowledge to the field. The management of these encounters has been suggested over time, improving treatment approaches in the clinical setting. This review aims to understand the pain and its types and intervention in the field of oral and maxillofacial surgery.

\section{Introduction}

Pain has loosely been known to be subjective in nature. ${ }^{1}$ This concept of pain has evolved and is usually described as sharp, dull, shooting, or throbbing because of bodily sensations. Although there are many theories of pain, such as Specificity Theory, Intensity Pattern, and Gate Control Theories, there are still questions on how pain is perceived. ${ }^{2}$

In 1986, the International Association for the Study of Pain (IASP) unanimously agreed that pain is defined as an "unpleasant sensory and an emotional experience with actual or potential tissue damage, or described tissue damage, or both.." Recently, there have been suggestions on the new definition of pain that connotes a shared experience, aside from being unpleasant. ${ }^{4}$ With that being stated, as of the year 2020, pain is now defined as "An unpleasant sensory and emotional experience associated with or resembling that associated with, actual or potential tissue damage." ${ }^{5}$

published online

May 31, 2021
DOI https://doi.org/

10.1055/s-0041-1725212

ISSN 1305-7456.
It was believed before that pain tendency leads to recovery, as it usually is adaptive. It is known to be comprised of different systems that are harmoniously functioning to recognize pain response. ${ }^{6}$

According to Coulthard et al, postoperative pain is protective in nature, permitting intact wound recuperation. ${ }^{7}$ Physiological aspects of pain render it necessary for human survival while pathologically, it pertains to a broader matter associated with the disease that caused it. ${ }^{8}$ The pathological pain greatly influences the quality of life and opens more therapeutic challenges. ${ }^{9}$

In dentistry, pain has been a familiar chief complaint of every patient who suffers from it. Dentists are aware that it is their mission to relieve this experience. Moreover, dental materials and drugs were developed to address the problems associated with this condition. ${ }^{10}$

After treating any oral and maxillofacial surgical procedure, pain management should be essential to the oral

(c) 2021. European Journal of Dentistry.

This is an open access article published by Thieme under the terms of the Creative Commons Attribution-NonDerivative-NonCommercial-License, permitting copying and reproduction so long as the original work is given appropriate credit. Contents may not be used for commercial purposes, or adapted, remixed, transformed or built upon. (https://creativecommons.org/licenses/by-nc-nd/4.0/). Thieme Medical and Scientific Publishers Pvt. Ltd. A-12, 2nd Floor, Sector 2, Noida-201301 UP, India 
surgeon's clinical setting. ${ }^{7}$ Since pain is sometimes inevitable, postoperative management continues to be a clinical dilemma even though there are advancements in the assessment and treatment of pain. ${ }^{11}$ Being one of the most significant factors in patient compliance, the concept of pain can deter patients from visiting the dentist. ${ }^{12}$ Understanding pain related to oral and maxillofacial surgery will help the clinician to manage it thoroughly.

This review presents the processes, pain encounters, and interventions associated with oral and maxillofacial surgical procedures.

\section{The Pain Processes}

Transmission of pain has always been thought to consist of a series of chemical mediators and neural releases that act synergistically. ${ }^{13}$ After a noxious stimulus occurs, such as when tissue injury commences, signals are sent to nociceptors that terminates in the brain to provoke the feeling of pain. These nociceptors are bidirectional, and the primary afferent fibers with their central and peripheral terminals arise from the same axon stalk. ${ }^{14}$

The process of identifying and signaling the existence of noxious stimuli is called nociception. ${ }^{7}$ The identifying involves the initiation of receptor potential caused by the primary afferent nociceptors (the $A \delta$ and $C$ fibers), which are myelinated and unmyelinated, respectively. ${ }^{14}$ This observable fact of activating the primary afferent nociceptors is called "peripheral sensitization." ${ }^{15}$ Consequently, these peripheral sensory neurons also send signals to the spinal and the supraspinal nuclei that later affect the brain. ${ }^{16}$ They are located in the dorsal root ganglion. ${ }^{17}$ However, in the case of the central neurons, they are situated in the spinal dorsal horn. ${ }^{8}$

The pain receptors involved in generating pain activate when an inflammatory reaction from an injury occurs. ${ }^{18}$ Usual signs that go hand in hand with inflammatory pain are swelling, erythema, color, rubor, and function laesa. ${ }^{19}$

\section{Pain Mediators}

According to Ricciotti and Fitzgerald, inflammation is a favorable response that indicates the repair of its structure and elimination of the causative agent. ${ }^{20}$ The inflammatory pain has a vital chemical mediator called bradykinin, which is a kinin. The kinins are processed by kininases that, if decreased, produce inflammation because of the acidic environment created. ${ }^{15}$

Bradykinin performs within its extent in many tissues and affects the sympathetic and sensory neurons. Its main action is to activate nociception as well as pain-production by vasodilation and smooth muscle contraction. ${ }^{16,21}$ Bradykinin is not only a mediator present in this process-since injury is apparent, but there are also these so-called eicosanoids that help with the production of inflammation.

Prostaglandin was said to enhance the nociceptive effects of bradykinin, thereby acting synergistically. ${ }^{22}$ The prostaglandins are messengers at the molecular level during injury as well in the inflammatory process. ${ }^{23}$ It is obtained from the arachidonic acid via the cyclooxygenase pathway (COX 1 and COX 2). ${ }^{14,24}$ This mediator is commonly viewed as a functional biological modulator that can cause inflammation. Still, according to the findings of Kawahara et al, it merely plays a crucial role in enhancing cytokine signaling. Prostaglandin was considered a robust pro-inflammatory mediator and is commonly blocked by nonsteroidal anti-inflammatory drugs (NSAIDs). ${ }^{25}$

On the other hand, thromboxane has an essential role in monitoring the functions of COX $2 .{ }^{13}$ In inflammation, this eicosanoid plays a role in platelet aggregation. ${ }^{17}$ It has been established that thromboxane aids in hemostasis and cardiovascular outcomes.

Leukotrienes, additionally, assist in vascular absorption and leukocyte chemotaxis. Both prostaglandins and leukotrienes claimed to control inflammatory pain. ${ }^{25,26}$

There is a simulative neuropeptide called substance $P$ that acts as a transmitter within the nociception system, released by bradykinin. ${ }^{21,27}$ It was believed to make use of chemical actions on circulatory and neural mechanisms. As a neurotransmitter, substance $P$ is also known to emerge from primary afferent neurons from the peripheral and central nerve endings. ${ }^{28}$ The main point of recognizing substance $P$ is that it is a biomarker for nociceptive neurons. ${ }^{20}$ Frequently, its presence is connected to neuropathic pain. ${ }^{29}$ Substance $P$ will help with the production of histamine generated by mast cells, thereby increasing vascular permeability and blood flow that causes inflammation. ${ }^{30}$

\section{Acute and Chronic Pain}

Acute pain happens right after an injury. A plethora of chemical mediators mentioned above comes into play immediately, resulting in pain response. ${ }^{31}$ Peripheral and central sensitization is involved in this type of pain, and their modulation is essential to alleviate it. ${ }^{32}$ Subsequently, chronic pain happens when the pain persisted even when the source of acute pain had been given intervention. ${ }^{33}$ Chronic pain is a complicated occurrence that differs from patient to patient, and the intensity and characteristics can vary as well. ${ }^{34}$

\section{Characteristics of Pain}

The mediators discussed are crucial in recognizing the types of pain. Understanding the characteristics of pain helps in diagnosis and treatment planning. The nature of postoperative dental pain is inflammatory, nociceptive, and neuropathic in origin. ${ }^{7,35}$ 


\section{Inflammatory Pain}

Inflammatory pain is produced after tissue injury as a response to actively performing vascular and nervous structures. It was known that the degree of pain commensurates to the tissue damage that was done and is precisely associated with tissue healing. ${ }^{36}$ Moreover, the hypersensitivity sensation is also indicative of inflammatory pain. ${ }^{37}$ The lesion would have the ability to repair itself and activates upon provocations. This, in turn, will lead to sensory reinforcement by either low or high stimuli. Since it is biological, this kind of pain can be reversed after repairing the injury unless a chronic condition intervenes. ${ }^{38}$ Activation of prostaglandin, bradykinin, leukotrienes, histamine were exhibited, and all of which are vital for tissue repair. ${ }^{7,35,39}$

\section{Nociceptive Pain}

Nociceptive pain is also protective in nature, similar to inflammatory pain. Furthermore, a distinctive feature of this kind of pain is that it warns the body from further harming itself. ${ }^{38,40}$ Additionally, it functions as a processor of severe conditions by pressure and temperature brought about by the nociceptors. ${ }^{41}$ Nociceptive pain exhibits a feeling of unpleasantness beyond bearable limits to maximize its protective capabilities. As mentioned earlier, these nociceptors are localized neurons that are peripherally equipped and operate as responders to noxious stimuli. ${ }^{22,43}$ Overflow of stimuli to nociceptors that causes injury to the central and somatic neurons can eventually lead to neuropathic pain. ${ }^{29,44}$

\section{Neuropathic Pain}

Neuropathic pain, as redefined by NeuPSIG and the International Association of the Study of Pain, is the "pain arising as a direct consequence of a lesion or disease affecting the somatosensory system." This entails that the pain comes from the lesion emerging from the peripheral or central nervous system. ${ }^{38,45}$ The associated peripheral disorders that lead to the progress of neuropathic pain are damages in the dorsal root ganglia and the spinal nerves. ${ }^{44}$ Neuropathic pain is described as burning, tingling, and stabbing sensations. ${ }^{35}$ It is usually maladaptive, and many patients have complained about it to be persistent. ${ }^{38,43}$ Contributing factors for this type of pain are the severity of the disease leading to chronicity and the time of surgery ${ }^{46}$ Nociceptors such as A-delta, C unmyelinated with A-beta fibers are involved with a high degree of exposure. ${ }^{47}$ Compared to inflammatory and nociceptive pain, this pain is due to the ailments in neural structures. ${ }^{40}$ Since it is not protective in nature, Klasser and Gremillion claimed that neuropathic pain does not support healing and repair. ${ }^{38}$

\section{Peripheral Painful Traumatic Trigeminal Neuropathies}

Associated with neuropathic pain is peripheral painful traumatic trigeminal neuropathies (PPTTN), which occurs 3 months after surgical involvement. Tendencies of PPTTN were attributed to nerve injuries (e.g., trigeminal nerve) after treatment. ${ }^{35,40}$ Often described as constantly burning and sometimes shooting pain, Sougoumarin et al mentioned that PPTTN also develops from peripheral to the central nervous system according to the IASP. ${ }^{48}$

According to Al-khateeb and Alnahar, prior research unanimously agrees that the patients undergoing minimally invasive surgeries such as uncomplicated tooth extraction, flapless surgeries, and small mucoperiosteal flaps have less postoperative pain, unlike traumatic dental and osseous surgeries. ${ }^{49}$ Understandably, the progression of acute pain to chronic pain is presented with multiple factors. ${ }^{50}$ It is also important to note that because of postoperative pain, the patients are postponing the visits to the dental setting. ${ }^{51}$ The pain in oral surgery usually starts as soon as the anesthetic diminishes within the day. ${ }^{52}$

\section{Dental Pain}

When the tooth becomes inflamed or traumatized, different types of pain mediators conglomerate, and the sensation is perceived as painful. ${ }^{53}$ The stimuli can activate sensory pain systems, especially in the dentin. The phenomenon has led to various theories, such as the hydrodynamic theory, in which the fluid in the dentinal tubules move, causing pain and is also known to have ion channels that contributed to tooth pain..$^{54}$ As usual, the pain that can be felt varies from person to person, and it has different characteristics. The toothache is the most common acute pain in dentistry, alongside pericoronitis, alveolar osteitis, and apical periodontitis. ${ }^{53}$

\section{Oral and Maxillofacial Procedures Causing Pain}

Several oral and maxillofacial surgery procedures cause pain, most likely in the postoperative period, when the healing process commences. The following procedures are described:

\section{Simple Extraction}

Simple extractions are the most frequently performed procedures in the oral surgery field at dental clinics. The pain is predicted to be less intense in these procedures than complicated ones, as it is of inflammatory type..$^{55}$ The tooth's precondition is also accounted for: the more inflamed and damaged tooth will consequentially be, the more painful the tooth postoperatively. ${ }^{49}$

In 1990, a study by Kim presented that $\mathrm{C}$ fibers are overstimulated with inflamed pulp than the sound tooth. ${ }^{66}$ This indicates that neuropathic pain can happen in simple extractions as well. ${ }^{57}$ Likewise, incisions from a scalpel are suggestive of nociceptive pain, which can taper off as the incision ends. ${ }^{37}$ Noxious stimuli can also be experienced by mechanical sectioning of the tooth as it produces heat and friction. ${ }^{56}$

In a study dedicated to premolar extractions by Chaushu et al, the authors documented swift healing; the pain was 
not a major predicament for 2 days. ${ }^{58}$ Persistent pain can also be expected but can be attributed to problems in the healing of the socket rather than nerve involvement. ${ }^{59}$

\section{Periapical Resection}

Chong and Pitt Ford's study showed that postoperative pain during root-end resection is sensed more during the first 3 to 5 hours, which reduces gradually. ${ }^{60}$ Slight pain and inflammation were described by Penarrocha et al during the first few days after apical surgery. The number of teeth and operation time were also considered factors with the expected degree of pain. ${ }^{36}$ Similarly, Kvist and Reit showed the same results as postoperative pain after the surgical retreatment of endodontic cases. ${ }^{61}$ Additionally, according to an analysis by García et al, the pain is intensified when the patient smokes, has poor oral hygiene, and when there was pre-existing pain before the periapical surgery. ${ }^{62}$

\section{Third Molar Surgery}

In cases of third molar surgeries, rare and severe complications often occur when the lingual nerve and inferior alveolar nerves get involved. ${ }^{63}$ Nerve injury was attributed to the operator's experience, use of improper armamentaria, and depth of impaction as the most critical factor. ${ }^{64}$ According to Berge, 1 to $5 \%$ of the patients who undergo surgical removal of impacted third molars have chronic neuropathic pain, which is less than those reported by the IASP. ${ }^{65}$ The pain nonetheless depends on the flap design with envelope flap, tooth sectioning, and vertical angulation related to less pain. ${ }^{66}$

However, in 2010, Sandhu et al reported that severe pain was experienced with the envelope flap compared to a bayonet flap for third molar surgery. ${ }^{67}$ As far as the depth of impaction is concerned, position $C$ was said to be correlated with severe pain in retrospect. ${ }^{68}$ The surgical time was also discussed to be a factor, naming that the lengthier the procedure, the more pain sequelae are expected because more inflammatory processes come into play. ${ }^{69,70}$

\section{Alveolar Osteitis}

Alveolar osteitis is a known complication in both routine exodontia and third molar surgery. ${ }^{71-73}$ Described to be a problem where there is a displacement of the blood clot and fibrinolysis, it occurs within 3 days after surgical intervention. ${ }^{52,73,74}$ Usually termed as "dry socket," it is characterized by intense pain, lasting from five to ten postoperative days. ${ }^{75}$ Thirty-eight percent of mandibular third molars are stated to have alveolar osteitis, compared to routine extractions. ${ }^{76}$ In a study by Benediktsdóttir et al, it was found that females were more at risk of experiencing dry sockets associated with pain than males. ${ }^{63}$ In a systematic review by Riba-Terés et al, it was inferred that bacteria might play a role in the pathogenesis of this condition. ${ }^{77}$

\section{Implant Placement}

Implant placement could cause neuropathic pain. Perioperative factors such as placement near the inferior alveolar nerve, causing a breach to its roof can ensue the neuropathic pain. According to Renton et al, paresthesia of the lower lip was a common problem while neuropathy was only secondary. ${ }^{78}$ In a review and case report by Rodriquez-Lozano et al, maxillary implant installation can also give rise to neuropathic pain as well. ${ }^{79}$ Generation of heat while placing the implant can be a factor and can be coupled with nerve injury. ${ }^{35,78}$ In contrast, Porporatti et al in 2017 reported that persistent pain was not exhibited by their subjects. ${ }^{80}$ Moreover, a 2020 study by Tabrizi et al reported that 40 patients who underwent both tooth extraction and dental implant surgery perceived dental implant placement as less painful. ${ }^{81}$

\section{Alveoloplasty}

In a case report by Yoo et al in 2015, routine alveoloplasties can also cause inflammation in the nerves causing neuropathic pain. The inflammation is due to the trauma and other somatosensory disorders encountered during the procedure. ${ }^{82}$ Alveoloplasty, when associated with emphysema because of the use of high-speed handpieces, can also cause severe pain and discomfort with crepitus on palpation, as reported by Dodge et al. ${ }^{83}$

\section{Orthognathic Surgery}

A study by D' Agostino et al reported insignificant pain and discomfort after orthognathic surgery. But $76 \%$ of the subjects experienced localized alteration of facial sensations. ${ }^{84}$ Bilateral sagittal split osteotomy (BSSO), on the other hand, was reported to have neuropathic pain in only $0.51 \%$ of the patients indicating that it has less risk of impinging the trigeminal nerve upon operation according to Politis et al in 2014. ${ }^{85}$ However, according to Kim, possible neuropathic pain was from exposing the inferior alveolar nerve and the structures within its extent. ${ }^{86}$ Furthermore, it was emphasized that BSSO and Le Fort I osteotomies simultaneously have more tremendous pain than other procedures in the oral and maxillofacial surgery field.$^{87}$ Neuropathic pain can be concluded as a direct aftermath of orthognathic surgery and trauma. ${ }^{88}$ Additionally, the pain was experienced by orthognathic surgery patients after a year with temporomandibular joint problems. ${ }^{89}$ The major structures that can be injured are the inferior alveolar nerve, mental nerve, incisive nerve, and the infraorbital nerve, and can have tremendous permanent damages. ${ }^{86}$

\section{Head and Neck Malignancy}

Malignancies in the head and neck region are essential for understanding the pain process. In a study with different oral pathologies by Eliav et al, the authors emphasized that the presence of malignancies can cause $A \beta$ afferents that may trigger inflammatory signaling, which may damage nerves in the oral region. ${ }^{47}$ On the other hand, oral metastasis is another entity featuring an undetected complication, they grow progressively and cause pain, among other symptoms. ${ }^{90}$ 


\section{Oral and Maxillofacial Trauma}

Oral and maxillofacial traumas typically need surgical interventions because of the presence of fractures in the mandible and the maxilla. In a retrospective study by Wusiman et al, these traumas are likely to happen more to young adults, and vehicle accidents are most likely the cause. ${ }^{91}$ The pain was noted to be the primary concern after the trauma and surgical involvement, significantly when the temporomandibular joint is affected. ${ }^{92-94}$ The quality of life of the patients who underwent invasive approaches deteriorated for the first 3 months after the operation. ${ }^{94}$ Facial fractures together with orthognathic surgery also predispose to post-traumatic neuropathy that can be iatrogenic. ${ }^{33}$

\section{Pain Assessments}

Visual analogue scale (VAS) is used in most of the studies that assess pain in oral, maxillofacial, and dental implant surgeries. VAS can be used preoperatively and more so postoperatively from the first to the seventh day, arbitrarily. This scale has an intensity range from 0 to 100 (no pain to worst pain). The pain scores are rather subjective as the patient indicates the pain based on his experience. ${ }^{11}$ The measurement validity is somewhat questionable, but with repeated application, reliability can be gained. ${ }^{95,96}$ Other studies rely on the use of analgesics alone or with the pain scale of their choice; the fewer the analgesics used, the lesser is the pain perceived by the patient. ${ }^{97,98}$

\section{Treatment for Acute Pain}

Since dentoalveolar surgery is the first and foremost framework of oral maxillofacial surgery, common pain relief agents are recommended. ${ }^{55}$ Nonopioid pain treatment such as acetaminophen (paracetamol) is known to have therapeutic effects on mild to moderate pain with added anti-inflammatory outcomes that can be used for postoperative pain. ${ }^{99} \mathrm{Al}-\mathrm{khateeb}$ and Alnahar also mentioned that commonly used postoperative medications are paracetamol and NSAIDs in extraction cases, and they recommended prescribing them in the first week. ${ }^{49}$ Since this operation commonly involves acute pain, simple, single dosed pharmacologic interventions are enough to be prescribed. ${ }^{100}$

The low-level laser therapy was also found to be effective in this type of surgery. According to Mozzati et al, super pulsed low-level laser after bilateral molar extractions is successful in lessening the pain because it inhibits inflammatory cytokines, suppresses cyclo-oxygenase $2\left(\mathrm{COX}_{2}\right)$, and activates bone remodeling that is beneficial in wound healing. ${ }^{101}$

Transdermal patches were used by Bhargava et al as a new method of pain control after routine tooth extractions. They compared ketoprofen and diclofenac patches with the ketoprofen patch demonstrating a more remarkable effect on pain, as the patients did not need any analgesics when applied. ${ }^{102}$

Single-dose analgesics are usually prescribed for pain from periapical surgeries, mostly experienced after 1 day. Tsesis et al used acetaminophen or naproxen sodium as their monotherapy. ${ }^{103}$ In another study by García et al, ibuprofen $600 \mathrm{mg}$ every 8 hours for 4 days was used for acute pain, and in severe pain, magnesium metamizole $575 \mathrm{mg}$ was used as needed. They focused on smokers and poor oral hygiene, and minimal pain was exhibited with the medications prescribed. ${ }^{104}$ Moreover, corticosteroids like dexamethasone had also been tried in this type of surgical procedure. Lin et al stated that dexamethasone and etodolac, nonsteroidal anti-inflammatory drugs, produce less pain and discomfort. ${ }^{105}$ Most third molar surgeries' pain control only requires analgesics for acute pain. Nevertheless, this was deemed to be inadequate sometimes for some patients. Combining medications, aside from single analgesic doses, are also evident to be effective in relieving pain after third molar removal operations. The aim is to decrease the doses of the drugs while simultaneously achieving sufficient analgesia, lessening the chances of adverse drug reactions..$^{51,106}$ In terms of analgesics, the combination comprises a peripherally acting drug and a centrally acting drug. An example would be acetaminophen and ibuprofen or diclofenac, or ketoprofen. ${ }^{107}$

In 2016, in a study done by Orozco-Solís et al, meloxicam $15 \mathrm{mg}$ was used preoperatively. It was reported that it produced a successful reduction of pain compared to diclofenac $100 \mathrm{mg}$ after the third molar operation. ${ }^{108}$ Tramadol usage has also been suggested in many studies as an efficient pain reliever after third molar surgeries. ${ }^{109,110}$

However, not only combination analgesics have been reported to enhance pain relief. Additionally, corticosteroids can also help. Corticosteroids also play a role in alleviating pain in oral and maxillofacial surgeries since they are known to suppress the cyclo-oxygenase and the lipoxygenase pathways. ${ }^{111}$ Corticosteroids like prednisolone, dexamethasone, methylprednisolone with analgesics are evidenced to maximize pain relief. These drugs are well documented, and the postoperative results have been promising. ${ }^{112}$ According to other literature, dexamethasone is applied via different routes in third molar surgeries, with the submucosal route showing superior effects. ${ }^{113-117}$

Platelet rich fibrin (PRF) in third molar surgery was involved in a randomized clinical trial in 2015, resulting in no significant differences of pain in the intervention and the control areas. ${ }^{118}$ However, a study by $\mathrm{Al}$-Hamed et al in 2016 with PRF said that it decreased pain more than promoting soft tissue healing, ${ }^{119}$ the mechanism of which includes the promotion of blood clots since this material is filled with growth factors and cytokines needed for recovery and pain reduction. ${ }^{120,121}$ 
Typically, the management of alveolar osteitis includes analgesic and antibiotic therapy and topical dressings. ${ }^{77}$ Recently, a new literature trend also indicated the use of PRF in treating this condition. A clinical trial by Sharma et al in 100 patients with alveolar osteitis proved that PRF can be useful in pain relief and wound healing. ${ }^{122}$ PRF was also compared with Alvogyl, a known antiseptic dressing indicated for alveolar osteitis, and results have shown that they have the same effect in reducing pain and enhancing healing. ${ }^{75}$ The evidence has deemed PRF to be a promising treatment modality in treating dry sockets.

Another clinical study was done in pain alleviation of dry socket, in which they used concentrated growth factor (CGF) and low-level laser therapy. With 60 patients in their study with one tooth involving dry socket, CGF was more successful than the low-level laser therapy. ${ }^{123}$

Treatment for pain after implant placement typically necessitates NSAIDs as the first line of pain control medication. Ibuprofen alone can be used after dental implant placement. ${ }^{124}$ Corticosteroids can also be used to lessen other postoperative sequelae. ${ }^{125}$ According to Bahammam et $\mathrm{al}$, dexamethasone given preoperatively and postoperatively evidently reduces pain. ${ }^{126}$ In 2006, a study by Buyukkurut et al, prednisolone $25 \mathrm{mg}$ with diclofenac given after surgery successfully minimized pain, swelling, and trismus. ${ }^{127}$ Methylprednisolone $40 \mathrm{mg}$ single dose injected in the masseter muscle in impacted third molars immediately after surgery was also deemed to be successful in postoperative sequelae. ${ }^{128}$

Alveoloplasty is usually associated with postoperative acute pain, thereby regular analgesics can be prescribed. From the case report of Dodge et al, the dentist prescribed prednisone and meloxicam among other medications. ${ }^{83}$

Preoperative tramadol and diclofenac sodium can also be used to promote postoperative analgesia in bimaxillary osteotomies. ${ }^{87}$ One observational study by Mobini et al in 2018 mentioned that analgesics for 24 hours are usually acetaminophen, oxycodone, and hydromorphone. ${ }^{129}$ The last two drugs are opioid analgesics, used for severe types of pain. Subsequently, opioids are suggested to be used with NSAIDs rather than taking them alone for maximum analgesic effect and less adverse reactions. ${ }^{130}$

Corticosteroids have also been routinely used in orthognathic surgery either preoperatively or postoperatively. ${ }^{131}$ A study by Abukawa et al in 2017 also advised the use of dexamethasone for BSSOs at $16 \mathrm{mg}$ intravenous route. ${ }^{132}$

Low-level laser therapy in BSSO and Le fort 1 was also reported by Gasperini et al The study showed an enhanced reduction of pain on succeeding follow-up days. ${ }^{92}$ By the evidence presented for osteotomies, we can extrapolate the same interventions for head and neck malignancies and facial traumas.

\section{Treatment for Persistent Pain}

Chronic pain treatment modalities are more complicated than acute pain that is usually expected in different surgical techniques above. In patients experiencing neuropathic pain following nerve injury and other iatrogenic factors from various procedures, analgesics can be recommended with other medications that can lessen pain. ${ }^{35,133}$ With all the pharmaceutical approaches that can be used hand in hand with analgesics, the British Dental Journal preferred using topically-applied treatments as an initial remedy before trying other methods. ${ }^{134}$ Moreover, gabapentin, carbamazepine, and tricyclic antidepressants were also known to reduce neuropathic pain with analgesics. .2, $^{235}$

The first line of drug treatments are tricyclic antidepressants, serotonin-noradrenaline reuptake inhibitors (SNRI), and anticonvulsants: pregabalin and gabapentin. ${ }^{136}$ Tricyclic antidepressants are known to inhibit neuropathic pain since they do not encourage suppressed pain and anxiety. ${ }^{137}$ Their action is nonselective and depends on the peripheral fibers in the dorsal root that supplies noradrenaline, a hormone highly regarded in the study of neuropathic pain because of its analgesic effect. ${ }^{137,138}$ However, SNRI has also been an effective modality without the side effects that come with the use of tricyclic antidepressants. Duloxetine is an example of an SNRI that can be well used in neuropathies associated with chemotherapy, which might be useful in head and neck cancer. ${ }^{139}$ Additionally, gabapentin and pregabalin are also efficient in neuropathic pain and well-tolerated as they decrease the influx of some monoamine neurotransmitters. ${ }^{138,140}$ Tramadol was also mentioned by studies to be proven effective in postoperative analgesia for neuropathic patients with chronic orofacial pain. ${ }^{33,136,141}$ Furthermore, Murnion particularly recommends tricyclic antidepressants and SNRI first, gabapentin and tramadol second if the first two are inadequate in relieving neuropathic pain. ${ }^{136}$

A systematic review by de Pedro et al on the use of low-level laser therapy suggested that it can be an effective modality in relieving orofacial neuropathic pain, but it needs further studies and more standardized methods. ${ }^{142}$ Moreover, in a general sense, the use of low-level laser therapy had encouraging results, in congruence with the review of de Pedro et al. ${ }^{143}$

In conclusion, different mechanisms are transpiring to produce pain. Pain-related to oral and maxillofacial surgeries and implant dentistry is unavoidable postoperatively, and it is important to know the mechanism and management of each. Various treatment modalities have been studied over time by researchers. Nonetheless, further studies about the pain linked with oral and maxillofacial surgery and implant dentistry and complex pain cases connected to oral surgery are recommended to equip clinicians in diverse settings. Many previous clinical studies with pain measurement and treatment in oral and maxillofacial surgery are summarized in - Table 1. ${ }^{35,79,82,92,106,108,119,121,126}$ 
Table 1 Studies involving different pain encountered in oral and maxillofacial surgery procedures

\begin{tabular}{|c|c|c|c|c|c|c|}
\hline Authors & Year & Research design & $\begin{array}{l}\text { Clinical } \\
\text { situation }\end{array}$ & $\begin{array}{l}\text { Pain } \\
\text { experienced }\end{array}$ & $\begin{array}{l}\text { Pain } \\
\text { measurement }\end{array}$ & Treatment \\
\hline $\begin{array}{l}\text { Rodríguez- } \\
\text { Lozano et al }{ }^{79}\end{array}$ & 2010 & $\begin{array}{l}\text { Review of literature } \\
\text { and case report }\end{array}$ & $\begin{array}{l}\text { Implant } \\
\text { placement in the } \\
\text { maxillary area }\end{array}$ & $\begin{array}{l}\text { Postoperative; } \\
\text { neuropathic pain }\end{array}$ & $N / A$ & $\begin{array}{l}\text { Lyrica (pregabalin) } \\
125 \text { mg/d } \\
\text { (for neuropathic pain) }\end{array}$ \\
\hline Gasperini et $a^{92}$ & 2014 & $\begin{array}{l}\text { Randomized } \\
\text { clinical trial }\end{array}$ & $\begin{array}{l}\text { Orthognathic } \\
\text { surgery }\end{array}$ & Postoperative & $\begin{array}{l}\text { Visual analog } \\
\text { scale }\end{array}$ & Low-level laser therapy \\
\hline $\begin{array}{l}\text { Delcanho and } \\
\text { Moncada }^{35}\end{array}$ & 2014 & $\begin{array}{l}\text { Review of literature } \\
\text { and case report }\end{array}$ & $\begin{array}{l}\text { Implant } \\
\text { placement in } \\
\text { the mandibular } \\
\text { area }\end{array}$ & $\begin{array}{l}\text { Postoperative; } \\
\text { peripheral } \\
\text { painful traumatic } \\
\text { trigeminal } \\
\text { neuropathy }\end{array}$ & $\mathrm{N} / \mathrm{A}$ & Not mentioned \\
\hline Kumar et al ${ }^{121}$ & 2015 & $\begin{array}{l}\text { Randomized } \\
\text { clinical trial }\end{array}$ & $\begin{array}{l}\text { Impacted } \\
\text { mandibular third } \\
\text { molars }\end{array}$ & Postoperative & $\begin{array}{l}\text { Visual analog } \\
\text { scale }\end{array}$ & Platelet-rich fibrin \\
\hline Yoo et al ${ }^{82}$ & 2015 & Case report & $\begin{array}{l}\text { Extracted } \\
\text { teeth and } \\
\text { alveoloplasty }\end{array}$ & $\begin{array}{l}\text { Postoperative; } \\
\text { posttraumatic } \\
\text { neuralgia }\end{array}$ & $\mathrm{N} / \mathrm{A}$ & Carbamazepine \\
\hline $\begin{array}{l}\text { Al-Hamed } \\
\text { et al }{ }^{119}\end{array}$ & 2017 & $\begin{array}{l}\text { Randomized } \\
\text { clinical trial }\end{array}$ & $\begin{array}{l}\text { Impacted } \\
\text { mandibular third } \\
\text { molars }\end{array}$ & Postoperative & $\begin{array}{l}\text { Visual analog } \\
\text { scale }\end{array}$ & Platelet-rich fibrin \\
\hline $\begin{array}{l}\text { Orozco-Solis, } \\
\text { et al }{ }^{108}\end{array}$ & 2016 & $\begin{array}{l}\text { Randomized } \\
\text { clinical trial }\end{array}$ & $\begin{array}{l}\text { Impacted } \\
\text { mandibular third } \\
\text { molars }\end{array}$ & Postoperative & $\begin{array}{l}\text { Visual analog } \\
\text { scale }\end{array}$ & Diclofenac; meloxicam \\
\hline $\begin{array}{l}\text { Bahammam } \\
\text { et al }{ }^{126}\end{array}$ & 2017 & $\begin{array}{l}\text { Randomized } \\
\text { clinical trial }\end{array}$ & $\begin{array}{l}\text { Implant } \\
\text { placement }\end{array}$ & Postoperative & $\begin{array}{l}\text { Visual analog } \\
\text { scale and verbal } \\
\text { rating scale }\end{array}$ & $\begin{array}{l}\text { Ibuprofen; } \\
\text { dexamethasone }\end{array}$ \\
\hline $\begin{array}{l}\text { Zupelari- } \\
\text { Goncalves } \\
\text { et al }{ }^{106}\end{array}$ & 2017 & $\begin{array}{l}\text { Randomized } \\
\text { clinical trial }\end{array}$ & $\begin{array}{l}\text { Mandibular third } \\
\text { molars }\end{array}$ & Postoperative & $\begin{array}{l}\text { Visual analog } \\
\text { scale }\end{array}$ & Diclofenac; codeine \\
\hline
\end{tabular}

\section{Limitations}

The review covers available literature related to pain in oral, maxillofacial surgery, and dental implant placement. Most of the literature vaguely explained the nature of pain, thereby just describing the process. Limited evidence is available for simple extractions; mostly case reports with unusual outcomes, but these are indeed expected.

In third molar surgeries, many combination drugs were used under randomized clinical trials that were not included in this study in detail because of varying outcomes. Corticosteroid use in extensive surgeries has scarce evidence. Finally, it was difficult to find literature on chronic pain related to oral and maxillofacial surgery.

\section{Authors' Contributions}

D.S. contributed toward methodology, formal analysis, investigation, data curation, and writing-original draft preparation. D.R. contributed toward conceptualization, validation, formal analysis, resources, writing-review and editing, gave final approval, and agreed to be accountable. B.P.B. contributed toward writing-review and editing and project administration. N.N. contributed toward visualization and agreed to be accountable. N.W. contributed toward conceptualization, supervision, and final approval.

\section{Funding}

None.

\section{Conflict of Interest}

None declared.

\section{References}

1 Koyama T, McHaffie JG, Laurienti PJ, Coghill RC. The subjective experience of pain: where expectations become reality. Proc Natl Acad Sci U S A 2005;102(36):12950-12955

2 Moayedi M, Davis KD. Theories of pain: from specificity to gate control. J Neurophysiol 2013;109(1):5-12

3 Kumar KH, Elavarasi P, David CM. Definition of pain and classification of pain disorders. J Adv Clin Res Insights 2016;3:87-90

4 Cohen M, Quintner J, van Rysewyk S. Reconsidering the international association for the study of pain definition of pain. Pain Rep 2018;3(2):e634

5 Raja SN, Carr DB, Cohen M, et al. The revised International Association for the Study of Pain definition of pain: concepts, challenges, and compromises. Pain 2020;161(9):1976-1982

6 Bolles RC, Fanselow MS. A perceptual-defensive-recuperative model of fear and pain. Behav Brain Sci 2010;3(2):291-301

7 Coulthard P, Bailey E, Patel N, Coulthard MB. Pain pathways and pre-emptive and protective analgesia for oral surgery. Oral Surg 2014;7(2):74-80

8 Gangadharan V, Kuner R. Pain hypersensitivity mechanisms at a glance. Dis Model Mech 2013;6(4):889-895

9 Kuner R. Central mechanisms of pathological pain. Nat Med 2010;16(11):1258-1266 
10 Brodin P, Orstavik D. Effects of therapeutic and pulp protecting materials on nerve transmission in vitro. Scand J Dent Res 1983;91(1):46-50

11 Svensson I, Sjöström B, Haljamäe H. Assessment of pain experiences after elective surgery. J Pain Symptom Manage 2000; 20(3):193-201

12 Sanikop S, Agrawal P, Patil S. Relationship between dental anxiety and pain perception during scaling. J Oral Sci 2011; 53(3):341-348

13 Dionne RA, Gordon SM, Rowan J, Kent A, Brahim JS. Dexamethasone suppresses peripheral prostanoid levels without analgesia in a clinical model of acute inflammation. J Oral Maxillofac Surg 2003;61(9):997-1003

$14 \mathrm{Su}$ Y-S. Molecular mechanism of inflammatory pain. World Journal of Anesthesiology 2014;3(1)71

15 Amaya F, Izumi Y, Matsuda M, Sasaki M. Tissue injury and related mediators of pain exacerbation. Curr Neuropharmacol 2013;11(6):592-597

16 Kulmatycki KM, Jamali F. Drug disease interactions: role of inflammatory mediators in pain and variability in analgesic drug response. J Pharm Pharm Sci 2007;10(4):554-566

17 Ong CK, Seymour RA. Pathogenesis of postoperative oral surgical pain. Anesth Prog 2003;50(1):5-17

18 Steranka LR, Manning DC, DeHaas CJ, et al. Bradykinin as a pain mediator: receptors are localized to sensory neurons, and antagonists have analgesic actions. Proc Natl Acad Sci U S A 1988;85(9):3245-3249

19 Takeuchi O, Akira S. Pattern recognition receptors and inflammation. Cell 2010;140(6):805-820

20 Ricciotti E, FitzGerald GA. Prostaglandins and inflammation. Arterioscler Thromb Vasc Biol 2011;31(5):986-1000

21 Hargreaves KM, Roszkowski MT, Swift JQ. Bradykinin and inflammatory pain. Agents Actions Suppl 1993;41:65-73

22 Campbell WI, Kendrick RW. Postoperative dental pain-a comparative study of anti-inflammatory and analgesic agents. Ulster Med J 1991;60(1):39-43

23 Fokunang C. Overview of non-steroidal anti-inflammatory drugs (NSAIDs) in resource limited countries. MOJ Toxicology 2018;4(1):5-13

24 Kawahara K, Hohjoh H, Inazumi T, Tsuchiya S, Sugimoto Y. Prostaglandin E2-induced inflammation: relevance of prostaglandin E receptors. Biochim Biophys Acta 2015;1851(4): 414-421

25 Hata AN, Breyer RM. Pharmacology and signaling of prostaglandin receptors: multiple roles in inflammation and immune modulation. Pharmacol Ther 2004;103(2):147-166

26 Schweizer A, Brom R, Glatt M, Bray MA. Leukotrienes reduce nociceptive responses to bradykinin. Eur J Pharmacol 1984;105(1-2):105-112

27 Kessler W, Kirchhoff C, Reeh PW, Handwerker HO. Excitation of cutaneous afferent nerve endings in vitro by a combination of inflammatory mediators and conditioning effect of substance P. Exp Brain Res 1992;91(3):467-476

28 Harrison S, Geppetti P. Substance p. Int J Biochem Cell Biol 2001;33(6):555-576

29 Epstein JB, Wilkie DJ, Fischer DJ, Kim YO, Villines D. Neuropathic and nociceptive pain in head and neck cancer patients receiving radiation therapy. Head Neck Oncol 2009;1:26

30 Sacerdote P, Levrini L. Peripheral mechanisms of dental pain: the role of substance P. Mediators Inflamm 2012;2012:951920

31 Sorkin LS, Wallace MS. Acute pain mechanisms. Surg Clin North Am 1999;79(2):213-229

32 Fletcher MC, Spera JF. Management of acute postoperative pain after oral surgery. Dent Clin North Am 2012;56(1):95-111, viii

33 Renton T. Oral surgery II: part 5. Chronic orofacial pain. Br Dent J 2017;223(11):826-836

34 Lavand'homme P. The progression from acute to chronic pain. Curr Opin Anaesthesiol 2011;24(5):545-550
35 Delcanho R, Moncada E. Persistent pain after dental implant placement: a case of implant-related nerve injury. J Am Dent Assoc 2014;145(12):1268-1271

36 Penarrocha M, Garcia B, Marti E, Balaguer J. Pain and inflammation after periapical surgery in 60 patients. J Oral Maxillofac Surg 2006;64(3):429-433

37 Kehlet H, Jensen TS, Woolf CJ. Persistent postsurgical pain: risk factors and prevention. Lancet 2006;367(9522):1618-1625

38 Klasser GD, Gremillion HA. Neuropathic orofacial pain patients in need of dental care. J Can Dent Assoc 2012;78:c83

39 Araújo RZ, Pintor Júnior AA, Sigua-Rodriguez EA, Olate S, Alves LC, de Castro WH. Pain control in third molar surgery. Int J Odontostomatol 2016;10:385-391

40 Benoliel R, Kahn J, Eliav E. Peripheral painful traumatic trigeminal neuropathies. Oral Dis 2012;18(4):317-332

41 Dubin AE, Patapoutian A. Nociceptors: the sensors of the pain pathway. J Clin Invest 2010;120(11):3760-3772

42 St John Smith E. Advances in understanding nociception and neuropathic pain. J Neurol 2018;265(2):231-238

43 Costigan M, Scholz J, Woolf CJ. Neuropathic pain: a maladaptive response of the nervous system to damage. Annu Rev Neurosci 2009;32:1-32

44 Nicholson B. Differential diagnosis: nociceptive and neuropathic pain. Am J Manag Care 2006;12(suppl 9) :S256-S262

45 Haanpää M, Attal N, Backonja M, et al. NeuPSIG guidelines on neuropathic pain assessment. Pain 2011;152(1):14-27

46 Koltzenburg M, Torebjörk HE, Wahren LK. Nociceptor modulated central sensitization causes mechanical hyperalgesia in acute chemogenic and chronic neuropathic pain. Brain 1994;117(Pt 3) :579-591

47 Eliav E, Teich S, Benoliel R, et al. Large myelinated nerve fiber hypersensitivity in oral malignancy. Oral Surg Oral Med Oral Pathol Oral Radiol Endod 2002;94(1):45-50

48 Sougoumarin D, Omeish N, DiebW, Moreau N, Braud A, BoucherY. Exploring the time course of painful post-traumatic trigeminal neuropathy: a pilot study. J Oral Med Oral Surg. 2020;26(3)

49 Al-Khateeb TH, Alnahar A. Pain experience after simple tooth extraction. J Oral Maxillofac Surg 2008;66(5):911-917

50 Vickers ER, Boocock H, Harris RD, et al. Analysis of the acute postoperative pain experience following oral surgery: identification of 'unaffected', 'disabled' and 'depressed, anxious and disabled' patient clusters. Aust Dent J 2006;51(1):69-77

51 Mehlisch DR. The efficacy of combination analgesic therapy in relieving dental pain. J Am Dent Assoc 2002;133(7):861-871

52 Haraji A, Rakhshan V, Khamverdi N, Alishahi HK. Effects of intra-alveolar placement of $0.2 \%$ chlorhexidine bioadhesive gel on dry socket incidence and postsurgical pain: a double-blind split-mouth randomized controlled clinical trial. J Orofac Pain 2013;27(3):256-262

53 Renton T. Dental (odontogenic) pain. Rev Pain 2011;5(1):2-7

54 Lee K, Lee BM, Park CK, Kim YH, Chung G. ion channels involved in tooth pain. Int J Mol Sci 2019;20(9):E2266

55 Adeyemo WL, Taiwo OA, Oderinu OH, Adeyemi MF, Ladeinde AL, Ogunlewe MO. Oral health-related quality of life following non-surgical (routine) tooth extraction: a pilot study. Contemp Clin Dent 2012;3(4):427-432

56 Kim S. Neurovascular interactions in the dental pulp in health and inflammation. J Endod 1990;16(2):48-53

57 Kohjitani A, Miyawaki T, Kasuya K, Shimada M. Sympathetic activity-mediated neuropathic facial pain following simple tooth extraction: a case report. Cranio 2002;20(2):135-138

58 Chaushu G, Becker A, Zeltser R, Vasker N, Branski S, Chaushu S. Patients' perceptions of recovery after routine extraction of healthy premolars. Am J Orthod Dentofacial Orthop 2007;131(2):170-175

59 Adeyemo WL, Ladeinde AL, Ogunlewe MO. Clinical evaluation of post-extraction site wound healing. J Contemp Dent Pract 2006;7(3):40-49 
60 Chong BS, Pitt Ford TR. Postoperative pain after root-end resection and filling. Oral Surg Oral Med Oral Pathol Oral Radiol Endod 2005;100(6):762-766

61 Kvist T, Reit C. Postoperative discomfort associated with surgical and nonsurgical endodontic retreatment. Endod Dent Traumatol 2000;16(2):71-74

62 García B, Larrazabal C, Peñarrocha M, Peñarrocha M. Pain and swelling in periapical surgery. A literature update. Med Oral Patol Oral Cir Bucal 2008;13(11):E726-E729

63 Benediktsdóttir IS, Wenzel A, Petersen JK, Hintze H. Mandibular third molar removal: risk indicators for extended operation time, postoperative pain, and complications. Oral Surg Oral Med Oral Pathol Oral Radiol Endod 2004;97(4):438-446

64 Mason DA. Lingual nerve damage following lower third molar surgery. Int J Oral Maxillofac Surg 1988;17(5):290-294

65 Berge TI. Incidence of chronic neuropathic pain subsequent to surgical removal of impacted third molars. Acta Odontol Scand 2002;60(2):108-112

66 Malkawi Z, Al-Omiri MK, Khraisat A. Risk indicators of postoperative complications following surgical extraction of lower third molars. Med Princ Pract 2011;20(4):321-325

67 Sandhu A, Sandhu S, Kaur T. Comparison of two different flap designs in the surgical removal of bilateral impacted mandibular third molars. Int J Oral Maxillofac Surg 2010;39(11):1091-1096

68 Yuasa H, Sugiura M. Clinical postoperative findings after removal of impacted mandibular third molars: prediction of postoperative facial swelling and pain based on preoperative variables. Br J Oral Maxillofac Surg 2004;42(3):209-214

69 Mobilio N, Vecchiatini R, Vasquez M, Calura G, Catapano S. Effect of flap design and duration of surgery on acute postoperative symptoms and signs after extraction of lower third molars: a randomized prospective study. J Dent Res Dent Clin Dent Prospect 2017;11(3):156-160

70 Oikarinen K. Postoperative pain after mandibular third-molar surgery. Acta Odontol Scand 1991;49(1):7-13

71 Bowe DC, Rogers S, Stassen LF. The management of dry socket/ alveolar osteitis. J Ir Dent Assoc 2011;57(6):305-310

72 Bui CH, Seldin EB, Dodson TB. Types, frequencies, and risk factors for complications after third molar extraction. J Oral Maxillofac Surg 2003;61(12):1379-1389

73 Tong DC, Al-Hassiny HH, Ain AB, Broadbent JM. Post-operative complications following dental extractions at the School of Dentistry, University of Otago. N Z Dent J 2014;110(2):51-55

74 Jerjes W, El-Maaytah M, Swinson B, et al. Experience versus complication rate in third molar surgery. Head Face Med 2006;2:14

75 Keshini MP, Shetty SK, Sundar S, Chandan SN, Manjula S. Assessment of healing using alvogyl and platelet rich fibrin in patients with dry socket-an evaluative study. Ann Maxillofac Surg 2020;10(2):320-324

76 Kolokythas A, Olech E, Miloro M. Alveolar osteitis: a comprehensive review of concepts and controversies. Int J Dent 2010;2010:249073

77 Riba-Terés N, Jorba-García A, Toledano-Serrabona J, Aguilar-Durán L, Figueiredo R, Valmaseda-Castellón E. Microbiota of alveolar osteitis after permanent tooth extractions: A systematic review. J Stomatol Oral Maxillofac Surg 2020;S2468-S7855. Doi:10.1016/j.jormas.2020.08.007

78 Renton T, Dawood A, Shah A, Searson L, Yilmaz Z. Post-implant neuropathy of the trigeminal nerve. A case series. Br Dent J 2012;212(11):E17

79 Rodríguez-Lozano FJ, Sanchez-Pérez A, Moya-Villaescusa MJ, Rodríguez-Lozano A, Sáez-Yuguero MR. Neuropathic orofacial pain after dental implant placement: review of the literature and case report. Oral Surg Oral Med Oral Pathol Oral Radiol Endod 2010;109(4):e8-e12

80 Porporatti AL, Bonjardim LR, Stuginski-Barbosa J. Bonfante EA, Costa YM, Rodrigues Conti PC. Pain from dental implant placement, inflammatory pulpitis pain, and neuropathic pain present different somatosensory profiles. J Oral Facial Pain Headache 2017;31(1):19-29

81 Tabrizi R, Mohajerani H, Nabtieh A, Shafiei S. Do patients have the same experience of pain following tooth extraction and dental implants? Ann Maxillofac Surg 2020;10(1):88-90

$82 \mathrm{Yoo} \mathrm{JH}, \mathrm{Oh} \mathrm{JH}$, Kang SH, Kim JB. Management of traumatic neuralgia in a patient with the extracted teeth and alveoloplasty: a case report. J Dent Anesth Pain Med 2015;15(4):241-245

83 Dodge A, Kreh K, Kofina V, Rawal SY. Sublingual emphysema following alveoloplasty: a case report. Clin Case Rep 2020;8(10):2051-2054

84 D’Agostino A, Trevisiol L, Gugole F, Bondí V, Nocini PF. Complications of orthognathic surgery: the inferior alveolar nerve. J Craniofac Surg 2010;21(4):1189-1195

85 Politis C, Lambrichts I, Agbaje JO. Neuropathic pain after orthognathic surgery. Oral Surg Oral Med Oral Pathol Oral Radiol 2014;117(2):e102-e107

86 Kim YK. Complications associated with orthognathic surgery. J Korean Assoc Oral Maxillofac Surg 2017;43(1):3-15

87 Tuzuner AM, Ucok C, Kucukyavuz Z, Alkis N, Alanoglu Z. Preoperative diclofenac sodium and tramadol for pain relief afterbimaxillary osteotomy.JOral MaxillofacSurg 2007;65(12): 2453-2458

88 Renton T. Persistent pain after dental surgery. Rev Pain 2011; 5(1):8-17

89 Agbaje J, Luyten J, Politis C. Pain complaints in patients undergoing orthognathic surgery. Pain Res Manag 2018;2018: 4235025

90 Kumar G, Manjunatha B. Metastatic tumors to the jaws and oral cavity. J Oral Maxillofac Pathol 2013;17(1):71-75

91 Wusiman P, Maimaitituerxun B, Guli, Saimaiti A, Moming A. Epidemiology and pattern of oral and maxillofacial trauma. J Craniofac Surg 2020;31(5):e517-e520

92 Gasperini G, Rodrigues de Siqueira IC, Rezende Costa L. Does low-level laser therapy decrease swelling and pain resulting from orthognathic surgery? Int J Oral Maxillofac Surg 2014;43(7):868-873

93 Vega LG. Reoperative mandibular trauma: management of posttraumatic mandibular deformities. Oral Maxillofac Surg Clin North Am 2011;23(1):47-vi doi:10.1016/j.coms.2010.12.003

94 Boljevic T, Vukcevic B, Pajic S, Pesic Z. Oral health-related quality of life of patients undergoing different treatment of facial fractures: the OHIP-14 questionnaire. Niger J Clin Pract 2019;22(9):1213-1217

95 Isik K, Unsal A, Kalayci A, Durmus E. Comparison of three pain scales after impacted third molar surgery. Oral Surg Oral Med Oral Pathol Oral Radiol Endod 2011;112(6):715-718

96 Sirintawat N, Sawang K, Chaiyasamut T, Wongsirichat N. Pain measurement in oral and maxillofacial surgery. J Dent Anesth Pain Med 2017;17(4):253-263

97 Gozali P, Boonsiriseth K, Kiattavornchareon S, Khanijou M, Wongsirichat N. Decreased post-operative pain using a sublingual injection of dexamethasone $(8 \mathrm{mg})$ in lower third molar surgery. J Dent Anesth Pain Med 2017;17(1):47-53

98 Simone JL, Jorge WA, Horliana AC, Canaval TG, Tortamano IP. Comparative analysis of preemptive analgesic effect of dexamethasone and diclofenac following third molar surgery. Braz Oral Res 2013;27(3):266-271

99 Schug SA, Manopas A. Update on the role of non-opioids for postoperative pain treatment. Best Pract Res Clin Anaesthesiol 2007;21(1):15-30

100 Moore RA, Derry S, McQuay HJ, Wiffen PJ. Single dose oral analgesics for acute postoperative pain in adults. Cochrane Database Syst Rev 2011;(9):CD008659

101 Mozzati M, Martinasso G, Cocero N, et al. Influence of superpulsed laser therapy on healing processes following tooth extraction. Photomed Laser Surg 2011;29(8):565-571 
102 Bhargava D, Thomas S, Beena S. Comparison between efficacy of transdermal ketoprofen and diclofenac patch in patients undergoing therapeutic extraction-a randomized prospective split mouth study. J Oral Maxillofac Surg 2019; 77(10):1998-2003

103 Tsesis I, Fuss Z, Lin S, Tilinger G, Peled M. Analysis of postoperative symptoms following surgical endodontic treatment. Quintessence Int 2003;34(10):756-760

104 García B, Penarrocha M, Martí E, Gay-Escodad C, von Arx T. Pain and swelling after periapical surgery related to oral hygiene and smoking. Oral Surg Oral Med Oral Pathol Oral Radiol Endod 2007;104(2):271-276

105 Lin S, Levin L, Emodi O. Abu El-Naaj I, Peled M. Etodolac versus dexamethasone effect in reduction of postoperative symptoms following surgical endodontic treatment: a double-blind study. Oral Surg Oral Med Oral Pathol Oral Radiol Endod 2006;101(6):814-817

106 Zupelari-Goncalves P, Weckwerth GM, Calvo AM, et al. Efficacy of oral diclofenac with or without codeine for pain control after invasive bilateral third molar extractions. Int J Oral Maxillofac Surg 2017;46(5):621-627

107 Moore PA, Hersh EV. Combining ibuprofen and acetaminophen for acute pain management after third-molar extractions: translating clinical research to dental practice. J Am Dent Assoc 2013;144(8):898-908

108 Orozco-Solís M, García-Ávalos Y, Pichardo-Ramírez C, et al. Single dose of diclofenac or meloxicam for control of pain, facial swelling, and trismus in oral surgery. Med Oral Patol Oral Cir Bucal 2016;21(1):e127-e134

109 Mishra H, Khan FA. A double-blind, placebo-controlled randomized comparison of pre and postoperative administration of ketorolac and tramadol for dental extraction pain. J Anaesthesiol Clin Pharmacol 2012;28(2): 221-225

110 Shaik M, Kumar J, Mobina S, Satyanarayana N, Sunitha P. Comparative study of tramadol and ketorolac in the pain management of third molar tooth extraction. J Coll Med Sci 2010;6(1):35-43

111 Kim K, Brar P, Jakubowski J, Kaltman S, Lopez E. The use of corticosteroids and nonsteroidal antiinflammatory medication for the management of pain and inflammation after third molar surgery: a review of the literature. Oral Surg Oral Med Oral Pathol Oral Radiol Endod 2009;107(5):630-640

112 Ngeow WC, Lim D. Do corticosteroids still have a role in the management of third molar surgery? Adv Ther 2016;33(7): 1105-1139

113 Brucoli M, De Andreis M, Bonaso M, Boffano P, Benech A. Comparative assessment of dexamethasone administration routes for the management of postoperative symptoms following third molar surgery. J Stomatol Oral Maxillofac Surg 2019;120(6):529-533

114 Noboa MM, Ramacciato JC, Teixeira RG, Vicentini CB, Groppo FC, Motta RHL. Evaluation of effects of two dexamethasone formulations in impacted third molar surgeries. Rev Dor São Paulo. 2014;15(3):163-168

115 Boonsiriseth K, Klongnoi B, Sirintawat N, Saengsirinavin C, Wongsirichat N. Comparative study of the effect of dexamethasone injection and consumption in lower third molar surgery. Int J Oral Maxillofac Surg 2012;41(2):244-247

116 Latt MM, Kiattavorncharoen S, Boonsiriseth K, Pairuchvej V, Wongsirichat $\mathrm{N}$. The efficacy of dexamethasone injection on postoperative pain in lower third molar surgery. J Dent Anesth Pain Med 2016;16(2):95-102

117 Moranon P, Chaiyasamut T, Sakdajeyont W, et al. Dexamethasone injection into pterygomandibular space versus sublingual space on post-operative sequalae of lower third molar intervention. J Clin Med Res 2019;11(7):501-508
118 Ozgul O, Senses F, Er N, et al. Efficacy of platelet rich fibrin in the reduction of the pain and swelling after impacted third molar surgery: randomized multicenter split-mouth clinical trial. Head Face Med 2015;11:37

119 Al-Hamed F, Tawfik M, Abdelfadil E. Clinical effects of platelet-rich fibrin (PRF) following surgical extraction of lower third molar. The Saudi Journal for Dental Research. 2017;8(1-2):19-25

120 Del Corso M, Vervelle A, Simonpieri A, et al. Current knowledge and perspectives for the use of platelet-rich plasma (PRP) and platelet-rich fibrin (PRF) in oral and maxillofacial surgery part 1: periodontal and dentoalveolar surgery. Curr Pharm Biotechnol 2012;13(7):1207-1230

121 Kumar N, Prasad K, Ramanujam L, K R, Dexith J, Chauhan A. Evaluation of treatment outcome after impacted mandibular third molar surgery with the use of autologous platelet-rich fibrin: a randomized controlled clinical study. J Oral Maxillofac Surg 2015;73(6):1042-1049

122 Sharma A, Aggarwal N, Rastogi S, Choudhury R, Tripathi S. Effectiveness of platelet-rich fibrin in the management of pain and delayed wound healing associated with established alveolar osteitis (dry socket). Eur J Dent 2017;11(4):508-513

123 Kamal A, Salman B, Razak NHA, Samsudin ABR. A comparative clinical study between concentrated growth factor and low-level laser therapy in the management of dry socket. Eur J Dent 2020;14(4):613-620

124 Pereira GM, Cota LO, Lima RP, Costa FO. Effect of preemptive analgesia with ibuprofen in the control of postoperative pain in dental implant surgeries: a randomized, triple-blind controlled clinical trial. J Clin Exp Dent 2020;12(1):e71-e78

125 Bryce G, Bomfim DI, Bassi GS. Pre- and post-operative management of dental implant placement. Part 1: management of post-operative pain. Br Dent J 2014;217(3):123-127

126 Bahammam MA, Kayal RA, Alasmari DS, et al. Comparison between dexamethasone and ibuprofen for postoperative pain prevention and control after surgical implant placement: a double-masked, parallel-group, placebo-controlled randomized clinical trial. J Periodontol 2017;88(1):69-77

127 Buyukkurt MC, Gungormus M, Kaya O. The effect of a single dose prednisolone with and without diclofenac on pain, trismus, and swelling after removal of mandibular third molars. J Oral Maxillofac Surg 2006;64(12):1761-1766

128 Vegas-Bustamante E, Micó-Llorens J, Gargallo-Albiol J, Satorres-Nieto M, Berini-Aytés L, Gay-Escoda C. Efficacy of methylprednisolone injected into the masseter muscle following the surgical extraction of impacted lower third molars. Int J Oral Maxillofac Surg 2008;37(3):260-263

129 Mobini A, Mehra P, Chigurupati R. Postoperative pain and opioid analgesic requirements after orthognathic surgery. J Oral Maxillofac Surg 2018;76(11):2285-2295

130 Moote C. Efficacy of nonsteroidal anti-inflammatory drugs in the management of postoperative pain. Drugs 1992;44(suppl5) :14-29, discussion 29-30

131 Chegini S, Dhariwal DK. Review of evidence for the use of steroids in orthognathic surgery. $\mathrm{Br} \mathrm{J}$ Oral Maxillofac Surg 2012;50(2):97-101

132 Abukawa H, Ogawa T, Kono M, Koizumi T, Kawase-Koga Y Chikazu D. Intravenous dexamethasone administration before orthognathic surgery reduces the postoperative edema of the masseter muscle: a randomized controlled trial. J Oral Maxillofac Surg 2017;75(6):1257-1262

133 Fukuda K, Ichinohe T, Kaneko Y. Pain management for nerve injury following dental implant surgery at Tokyo Dental College Hospital. Int J Dent 2012;2012:209474

134 Khawaja N, Yilmaz Z, Renton T. Case studies illustrating the management of trigeminal neuropathic pain using topical 5\% lidocaine plasters. Br J Pain 2013;7(2):107-113 
135 Smith BH, Lee J, Price C, Baranowski AP. Neuropathic pain: a pathway for care developed by the British Pain Society. $\mathrm{Br}$ J Anaesth 2013;111(1):73-79

136 Murnion BP. Neuropathic pain: current definition and review of drug treatment. Aust Prescr 2018;41(3):60-63

137 Obata H. Analgesic mechanisms of antidepressants for neuropathic pain. Int J Mol Sci 2017;18(11):E2483

138 Fornasari D. Pharmacotherapy for neuropathic pain: a review. Pain Ther 2017;6(suppl 1):25-33

139 Hershman DL, Lacchetti C, Loprinzi CL. Prevention and management of chemotherapy-induced peripheral neuropathy in survivors of adult cancers: American Society of Clinical Oncology Clinical Practice Guideline Summary. J Oncol Pract 2014;10(6):e421-e424
140 TaylorCP, Gee NS, SuTZ, et al. A summary of mechanistic hypotheses of gabapentin pharmacology. Epilepsy Res 1998;29(3): 233-249

141 Iwata K, Imamura Y, Honda K, Shinoda M. Physiological mechanisms of neuropathic pain: the orofacial region. Int Rev Neurobiol 2011;97:227-250

142 de Pedro M, López-Pintor RM, de la Hoz-Aizpurua JL, Casañas E, Hernández G. Efficacy of low-level laser therapy for the therapeutic management of neuropathic orofacial pain: a systematic review. J Oral Facial Pain Headache 2020;34(1):13-30

143 de Andrade AL, Bossini PS, Parizotto NA. Use of low level laser therapy to control neuropathic pain: a systematic review. J Photochem Photobiol B 2016;164:36-42 